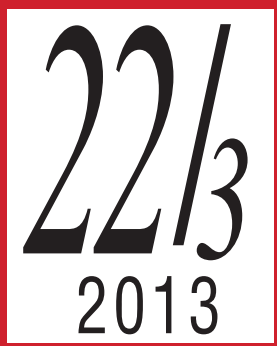

\title{
Ethnomusicology Forum
}

THE HUMAN AND NON-HUMAN IN LOWLAND SOUTH AMERICAN INDIGENOUS MUSIC

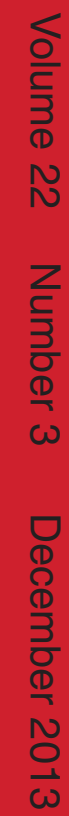

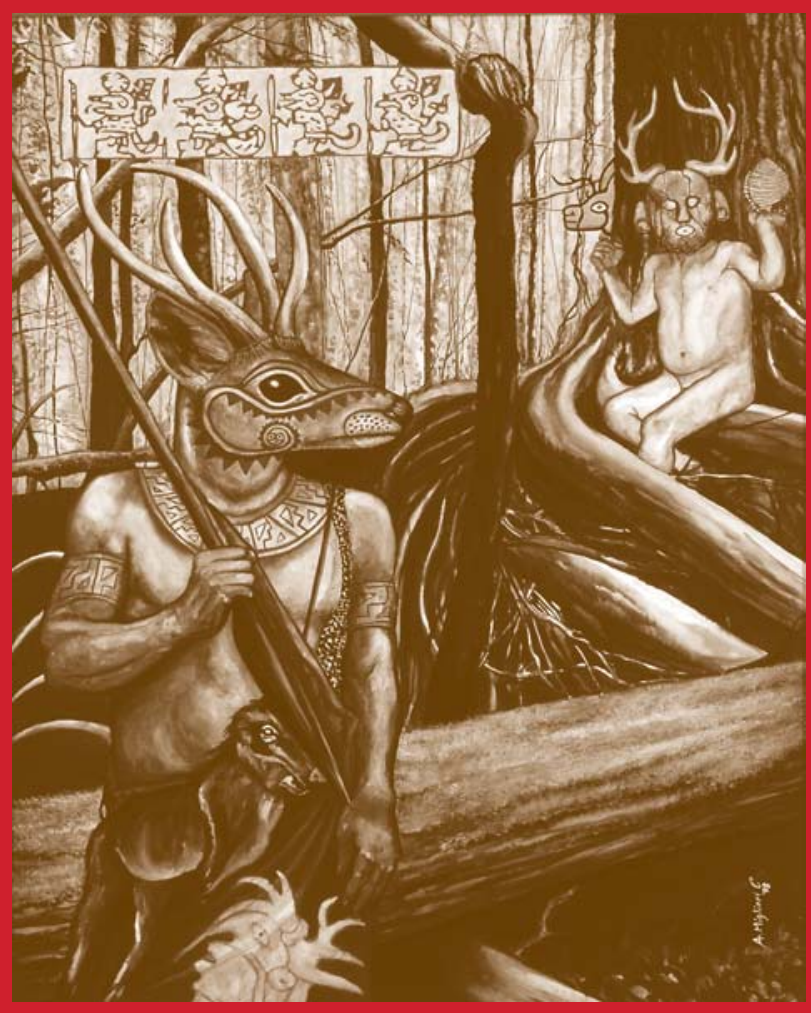

\footnotetext{
Routledge

茼 Taylor \& Francis Group ISSN 1741-1912
} 


\section{Ethnomusicology Forum}

SPECIAL ISSUE: The Human and Non-human in Lowland South American Indigenous Music GUEST EDITOR: Bernd Brabec de Mori

Editorial

Trevor Wiggins, Eleni Kallimopoulou \& Simone Krüger

Introduction: Considering Music, Humans, and Non-humans

Bernd Brabec de Mori \& Anthony Seeger

Apùap World Hearing Revisited: Talking with 'Animals', 'Spirits' and other Beings, and Listening to the Apparently Inaudible

Rafael José de Menezes Bastos

Flutes, Songs and Dreams: Cycles of Creation and Musical Performance among the Wauja of the Upper Xingu (Brazil)

Acácio Tadeu de Camargo Piedade

Instruments of Power: Musicalising the Other in Lowland South America Jonathan D. Hill

Shipibo Laughing Songs and the Transformative Faculty: Performing or Becoming the Other

Bernd Brabec de Mori

Focusing Perspectives and Establishing Boundaries and Power: Why the Suyá/ Kïsêdjê Sing for the Whites in the Twenty-first Century

Anthony Seeger
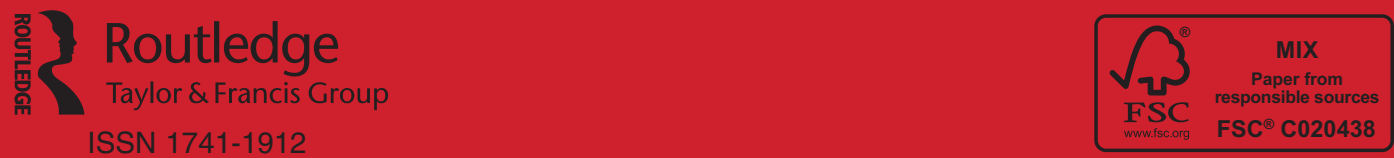


\title{
Shipibo Laughing Songs and the Transformative Faculty: Performing or Becoming the Other
}

\author{
Bernd Brabec de Mori
}

Shipibo indigenous people perform a sophisticated array of vocal musical genres, including short 'laughing songs' called osanti. These song-jokes make fun of certain non-humans, mostly animals. They are by definition sung from within the nonhumans' perspective. Osanti are only performed by trained specialists in indigenous medicine and sorcery (médicos), because it is crucial that the performer owns the faculty of transforming into the animal in question, although in osanti the singers do not transform. Songs involving actual transformation are not meant for laughing: these are magical songs including interaction with and transformation into animals or spirits that possess a more ample radius of perception and action than 'Real Human' beings. Osanti songs, with their position between secular and magical songs, allow for an analysis of humour and laughing in the construction of the indigenous ontology, thereby questioning some generalisations made in theories of animism and perspectivism.

Keywords: Shipibo-Konibo; Humour; Vocal Music; Magic; Perspectivism

\section{Introduction}

Relations between humans and non-humans are the subject of many indigenous rituals and are usually considered very serious by researchers, but they can also be funny. This paper is about a specific song genre called osanti ('to laugh'), performed among Shipibo-Konibo indigenous people (henceforth Shipibo). Osanti songs express differences between people and certain non-humans, mostly animals, in a way that

\footnotetext{
Bernd Brabec de Mori received his PhD in musicology from the University of Vienna, Austria. He specialised in indigenous music from the Ucayali valley in Eastern Peru, where he spent some years among the indigenous group Shipibo-Konibo. He is currently Senior Scientist at the Institute of Ethnomusicology, University of Music and Performing Arts, Graz, Austria. His publications contribute to the research areas of western Amazonian indigenous music, arts and history as well as the complex of music, ritual and altered states. Correspondence to: Bernd Brabec de Mori, Institute of Ethnomusicology, Leonhardstraße 81-83, 8010 Graz, Austria. Email: bernd.brabec@kug.ac.at
} 
provokes laughter among singers and listeners of this indigenous group. Although humour appears to be a highly cultural category, laughing and making fun seem to bridge borders and social gaps. Likewise, sung words, in Shipibo context, are thought to be comprehended also by non-Shipibo Others. Therefore it is rewarding to analyse the role of humour and song-specifically of humorous singing-in the complex negotiations of the boundaries between humans and non-humans. ${ }^{1}$ The aim of this contribution lies in investigating the functions of laughing and singing in the construction and maintenance of boundaries between the Shipibo people and their environment.

The Shipibo, who number as many as 50,000, live mainly along the Ucayali river and its tributaries in the lowland rainforests of Eastern Peru. They are well known among both researchers and tourists for their spectacular artwork in embroidered and painted patterns (see Figure 1; cf. Tessmann 1928: 40, 49 and 62), as well as for their sophisticated use of the hallucinogenic plant brew ayawaska in their indigenous medicine. $^{2}$

Shipibo as well as Konibo are not autodenominations in the strict sense. Although today, most of them will say that they consider themselves 'Shipibo', the

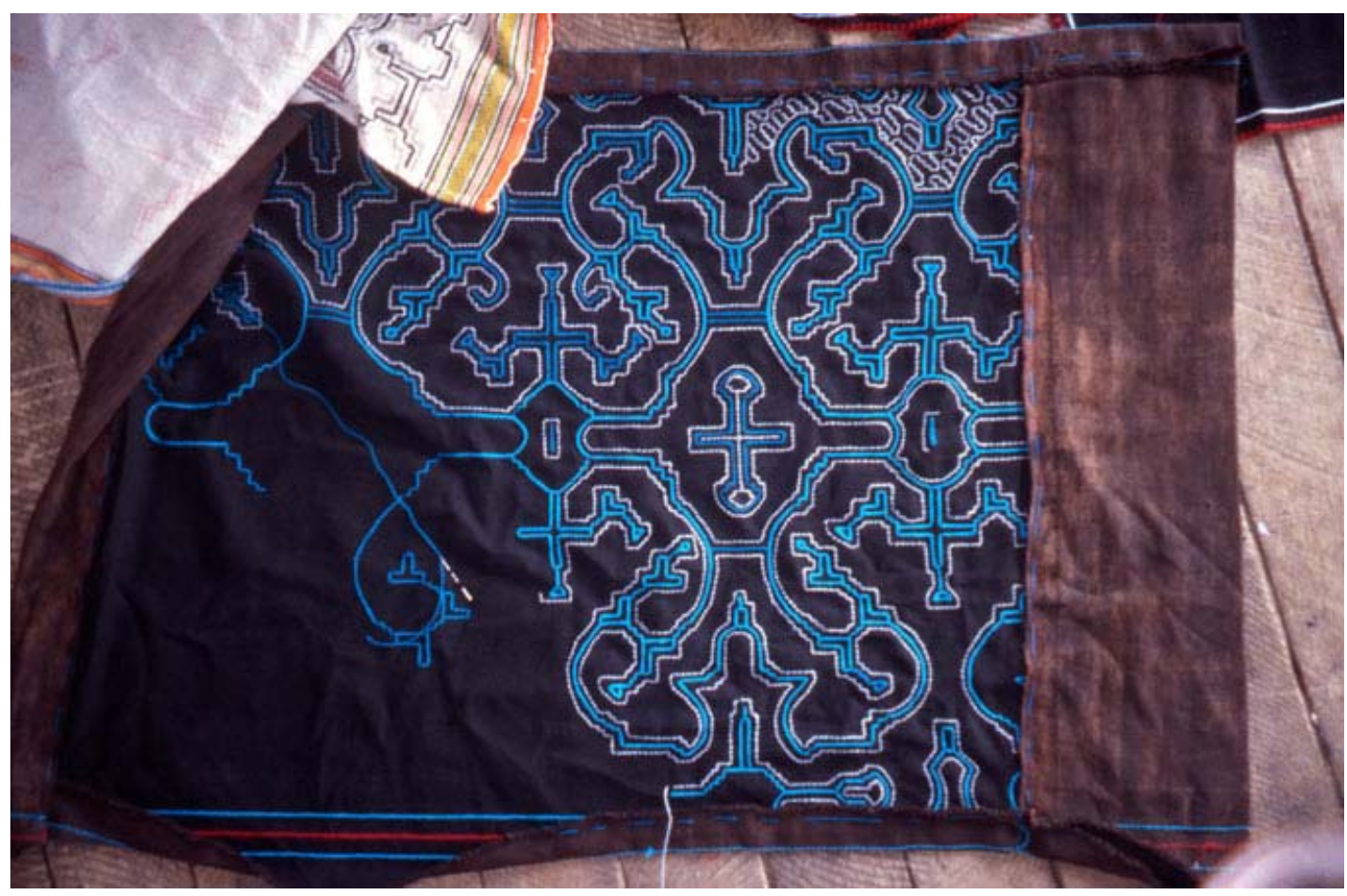

Figure $1 \mathrm{~A}$ textile sheet with kené patterns during the process of embroidering.

\footnotetext{
${ }^{1}$ For a definition of how I use human versus non-human see the introductory essay in this volume.

${ }^{2}$ For a comprehensive compendium on preparation, uses and contexts of ayawaska see the volume edited by Labate and Araujo (2004); for its history in the Peruvian lowlands, see Brabec de Mori (2011c). For the relations between music, artwork and indigenous medicine, see Brabec de Mori (2011b) and Brabec de Mori and Mori Silvano de Brabec (2009).
} 
vernacular autodenomination is noa jonikon, 'We the Real People'. Throughout this paper, I will use Real People (with upper-case initials) in order to refer to people from the same group, depending on perspective: from a Shipibo's point of view, other Shipibo are Real People; from a jaguar's point of view, other jaguars are Real People. This terminology is in tune with Amerindian perspectivism, following the concept of cosmological deixis established by Viveiros de Castro (1998: 476), who points out that the 'people' category, besides embracing other human beings like neighbouring indigenous populations, Peruvian mestizos or whites, further extends among animals and even plants or rivers and mountains, for example. It is the respective point of view, the perspective, that defines 'we'; that is, who pertains to the Real People. The validity of perspectivism is not unchallenged, and debating perspectivism and animism (Descola 2005) is a central issue in the present volume (see also the dossier edited by Halbmayer 2012b). In the introduction to this issue it was considered that the theories of Descola and Viveiros de Castro, among others, cannot be applied without confronting inconsistencies (see also Hill and Bastos, this issue). In general, both authors are too quick in assuming an encompassing cosmology for Amerindian societies. I prefer the interpretation by Halbmayer (2012a, quoted in detail in the introduction to this issue) who proposes a multiverse with multiple overlapping and non-encompassing layers of reality, specific not only for humans, animals and spirits but also for things and social entities (e.g., villages). Interactions of humans and non-humans therefore are constituted by complex and contingent relations that have to be permanently negotiated, processes Halbmayer calls 'politics of fragile inter-species and multiworld border management' (2012a: 119). Therefore I will later turn to the sociological concept of boundary work as a tool for analysing these negotiations.

The material presented in this contribution was recorded and evaluated during my own fieldwork among the Shipibo and neighbouring groups from 2001 to 2006 (see Brabec de Mori 2011a). Selection, translation and interpretation has been undertaken in close cooperation with the singers themselves, bilingual native teachers and other native experts who commented on the work in progress. The short and funny animal songs osanti were hitherto only mentioned by Illius (1999: 227-30) and Brabec de Mori (2011a: 417-30 and 881-92, where the examples in this text are taken from). In order to comprehend osanti and their performance contexts, in the following section I will first outline Shipibo vocal music and its functions, then the form and function of humour, and the concept of boundary work. Thereafter, osanti songs and related genres will be presented, analysed and juxtaposed to magical songs dealing with animals in different ways. Finally I will propose answers to some questions: What is funny about these short animal songs? Why is their performance restricted to specialists? How do laughter and singing contribute to boundary work that establishes and maintains the singers' and their communities' position in their environment? And how can humour and song help in criticising and developing existing theories on personhood and indigenous cosmology? 


\section{Songs, Humour and Boundary Work}

Shipibo people employ a rich and developed music theory, especially regarding vocal music (see Brabec de Mori 2011a: 284-309). They distinguish mainly three categories of songs, which are defined by their melodic-rhythmic form. The first, mashá, denotes both a round dance and its accompanying song, commonly performed at atsa xeati (manioc [cassava] beer) drinking festivals. This form is defined by a successively accelerating four-beat rhythm with sequences of repeated phrases, which are usually preceded by a higher pitched introductory phrase. The shiro bewá is a line dance with its accompanying song, likewise performed mostly at festivals. Its phrase structure moves in four-beat or five-beat rhythms along a generally descending melodic line, lacking the mashás repeated phrases. Finally, the bewá is generally performed at a slower tempo, with more fermata and often exhibits a symmetric phrase structure. It is performed at festivals, but also in private and is not accompanied by dance. ${ }^{3}$ On the other hand, Shipibo people name and distinguish many song topics (e.g., nokon chaibetan xeaitian iká, 'sung when drinking together with my brother-in-law'), which can be grouped in what I call genres, for example: drinking songs, love songs, songs for welcome or departure (which I categorise as non-magical songs), as well as curing, protection or sorcery songs (i.e., magical songs) and also the osanti laughing songs. These genres are usually performed applying either mashá, shiro bewá or bewá musical forms. A distinction between magical and non-magical songs is not named by Shipibo but they precisely distinguish them by context, intention and performer: a magical song can only be performed by trained specialists (i.e., by healers and sorcerers, who I am going to call médicos in this paper), ${ }^{4}$ it should change circumstances or states of persons (e.g., in order to cure illness), and it is performed in rituals or in situations when asked for by a client. Magical songs likewise make use of the formal categories mashá, shiro bewá or bewá, and additionally ikaro, a vocal form limited to magical songs. ${ }^{5}$

The attentive reader may have noticed that I have not yet defined a magical or non-magical status for osanti songs. This is not obvious because osanti can only be performed by médicos but, at the same time, they are not thought to change circumstances. Maybe they are neither magical nor non-magical, or both; but anyway, osanti songs are funny, so let us turn to the topic of humour for the moment.

Humour and laughing in general rank among the less studied phenomena, especially in the anthropology of Lowland South American societies (but see Beaudet 1996; Lagrou 2006; Overing 2000). A seminal work about humour and power was

\footnotetext{
${ }^{3}$ Certain ritual songs (nawarin, ai iká, ishori and ikaro) represent their own formal category. A detailed treatment of these songs and their formal characteristics is given by Brabec de Mori (2011a: 395-444).

${ }^{4}$ In Shipibo language, the corresponding terms are yobé (dart warfare specialist) and meráya (specialist in transformation). However, in Ucayali indigenous discourse, the reinterpreted Spanish term médico is most often applied also by the specialists themselves. Throughout this paper I will use male forms with this term, because most practitioners are males (93\% in my survey).

${ }^{5}$ Ikaro is a form of vocal music known and applied among most populations in the Peruvian lowlands. It is associated with, although not restricted to, the use of ayawaska in curing or sorcery rituals. Among the Shipibo it was introduced together with ayawaska from the north, probably around 1800 (cf. Brabec de Mori 2011c).
} 
published by Radcliffe-Brown, who proposes that among many societies on earth, people make fun of each other in more or less formal, symmetrically or asymmetrically constructed relationships 'of mutual disrespect and licence. Any serious hostility is prevented by the playful antagonism of teasing' (1940: 197-8). In the western Amazon, such 'joking relationships' are very common among in-laws, or between grandparents and grandchildren. Joking in such relationships, but also in general, is called shiroi among Shipibo and is highly esteemed. For example, one man told me that he managed to stay unnoticed while knotting a short rope to both a pillar and to his brother-in-law's belt while they were sitting on a platform and chatting. He teased the victim that for sure he could not jump to the other platform, about two metres away and separated by water. The victim tried, with the predictable result. People who excel in (sometimes fairly dolorous or bawdy) joking are called shiromis by peers and many say, in a sense of ethnic identification, that Shipibo in general are kikin shiromis, 'real jokers'. ${ }^{6}$ Similarly, joking towards outsiders is important and often takes the form of tall tales or ridiculous events that the victim is made to believe. After the poor person's departure, the jokers would often literally roll on the floor laughing. Even worse if this happened publicly: a white woman who worked in a non-governmental organisation project was taught by malicious Shipibo that, in their language, 'gentlemen' was expressed with boshirashki, and she should use this term to address the village's authorities when presenting her project. She did, and the rest is history, as the reader might imagine. Likewise I was told on my first days among Shipibo that being very nice to a young woman was expressed with xebi noe. I suspected something, and asked a female Shipibo friend what this meant. She was earnestly upset about her peers' unmannerliness.

These anecdotes illustrate that in many instances laughter explicitly deals with alterity and humour is used in order to work on boundaries. 'Foreigners are funny', states Critchley (2002: 67), because 'Humour is a form of cultural insider-knowledge [...]. Its ostensive untranslatability endows native speakers with a palpable sense of their cultural distinctiveness or even superiority'. In jokes about foreigners, these are commonly either stupid or canny, and both can be understood as a sort of prejudicial categorising them as inferior to the ones who laugh (The Superiority Theory of Humour, see Carroll 2003: 345). On the other hand, humour can be an effective tool in bridging boundaries, for instance when a foreign field researcher starts out among a community still alien to him or her (Driessen 1997; Illius 2003). In such cases, humour and laughing allow an Alien entity to be changed to an Other, an Other that can be understood and dealt with (one cannot deal with an Alien). We will see that

\footnotetext{
${ }^{6}$ The verb shiroi is also used in the musical form shiro bewá. Shiroi can be translated as 'to joke' but its meaning extends much further: courting is subsumed in shiroi, as well as formalised speech for expressing jealousy or loss of relationships, or formalised invitations for fighting and drinking together at a festival. Therefore, shiroi circumscribes fairly exactly the scope of 'good life' or 'living well' (cf. Gow 2000). Accordingly, the predominant topics performed in the shiro bewá vocal form are drinking, courtship, loss of relationships, welcome and departure.

${ }^{7}$ This term and also the following are so obscene that I refrain from translating here. For obscenities in names see also Driessen (1997)
} 
much—although not all_of the laughing about animals in osanti songs may be understood as pertaining to one of these two boundary processes: superiority and othering.

Boundary work as an analytical concept was introduced in the early 1980s by Thomas Gieryn (1995: 441) as a tool for studying the margins of science and technology. This concept has since then been used in sociological analysis of border processes in general terms (see Pachucki, Pendergrass and Lamont 2007). Tanja Paulitz (2012: 47-58) implements in boundary work what Foucault had to say about knowledge and power, adds Bourdieu's actors and habitus, and therefore provides a powerful tool for analysing processes of othering. When Gieryn mentions 'four types of boundary-work: monopolization, expansion, expulsion, and protection' (1995: 424), one may be reminded of methods used by Shipibo médicos for underlining their distinction among Shipibo laypeople, as well as for their negotiations with nonhumans or non-Real People, aiming for their own group's effective positioning in the cosmos. Here, Halbmayer's 'fragile inter-species and multi-world border management' comes into play as the main occupation of indigenous healers and sorcerers. If dealing with non-humans-including spirits, animals and in the present case nonShipibo indigenous, mestizo or white people-mainly consists of imminently performed boundary work, I will in the following pages elucidate where and how singing and laughter enter into these dealings and what their functions or effects may be.

\section{Osanti Songs: Performing the Other}

Osanti are short funny songs. Their melodic and rhythmic structure is borrowed from the aforementioned mashá and shiro bewá forms but, unlike those, they are not performed at festivals or accompanied by dance. When analysing them as isolated pieces, the most obvious difference from other categories of song is their short duration, a few seconds up to a maximum of about one minute. Further on, in their adaptation of a mashá or shiro bewá form, there is most often an error included, as if the singer would not know how to sing correctly according to emic aesthetic criteria: the tempo may be too fast, for example, or melodic lines not well developed. Quite contrarily, festival songs as well as magical songs are always intended to exploit the singer's aesthetic knowledge and singing abilities to the maximum. It is very important for Shipibo singers to perform as perfectly as possible.

Osanti are sung from the perspective of animals or, more seldom, of plants or demons. Animals and other non-humans play a prominent role in almost all songs performed by Shipibo (and throughout the indigenous western Amazon). However, these roles are multiple: in non-magical songs, people who are mentioned in the lyrics are in general substituted by animal names (cf. Brabec de Mori 2011b). These metaphors or codes are shared, so any culturally educated Shipibo understands them. In a festive shiro bewá, the singer may also use a metaphorical code for himself or herself, but this is never meant literally. In magical song lyrics, on the other hand, 


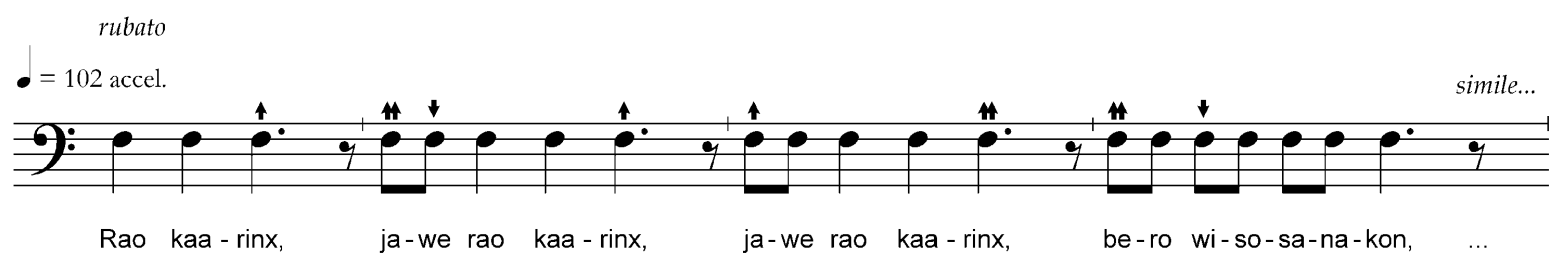

Figure 2 Transcription of the beginning of the land tortoise's song.

non-human names are never used to substitute present people (patients or family members). These are addressed from a 'safe distance' while the non-humans' positionalities remain unclear; the lyrics are often coded and twisted (Townsley 1993). The singer may disguise as a non-human, masking his voice or hinting at his transformation in the lyrics, but this is not made obvious although it is meant literally. But in osanti songs, the role of animals is explicit: they are the singers.

Osanti songs are usually performed before or during, but most often after healing sessions, and only by the specialists. For instance, a highly renowned Shipibo médico, who left us in 2008, used to sing the tortoise's osanti (see Figure 2) after treating severely ill people. In the dark of night, he shifted his body posture in order to appear like a tortoise and sang its mashá, imitating the tortoise by his movements. He told me that if the patient then laughed, his healing would be successful; if not, the patient would be doomed. Here, the osanti song serves as a tool for post-treatment diagnosis, a test if the patient was again brought back to 'correct' human life.

Illius, contrarily, describes osanti songs as entertainment provided by the specialists in order to educate children:

The meráya, mighty priest-shamans of old, besides their function as healers, also had the duty to educate and entertain children. Every night, these medicinal-religious functionaries provided show performances of their 'art of transformation' which not only contributed to strengthen their reputation as equally powerful enemies of the yoshinbo [demons], but also simply served as entertainment. [...S]pirits were depicted as ridiculous by any means and sometimes one could even interpret some self-irony of the meráya. (Illius 1999: 227; my translation)

Illius is certainly correct in interpreting osanti song performances as ridiculous renderings of the meráya's transformative faculty. They are entertainment, although I doubt that they would be specifically dedicated to children. In my own experience, osanti were more often performed in the absence of children. There are also Shipibo children's songs but these always apply third-person addressing for animals. Children make fun, for example, of three small pigs who go bathing to the beach despite their mother's warning and are eaten by a jaguar (cf. Brabec de Mori 2011a: 473-7). Children, along with Shipibo laypeople, would never dare to sing osanti. For instance, before I grasped this and believed that osanti were children's songs, one day I sang some osanti I had heard beforehand to a few boys in a Shipibo village, just for fun. 


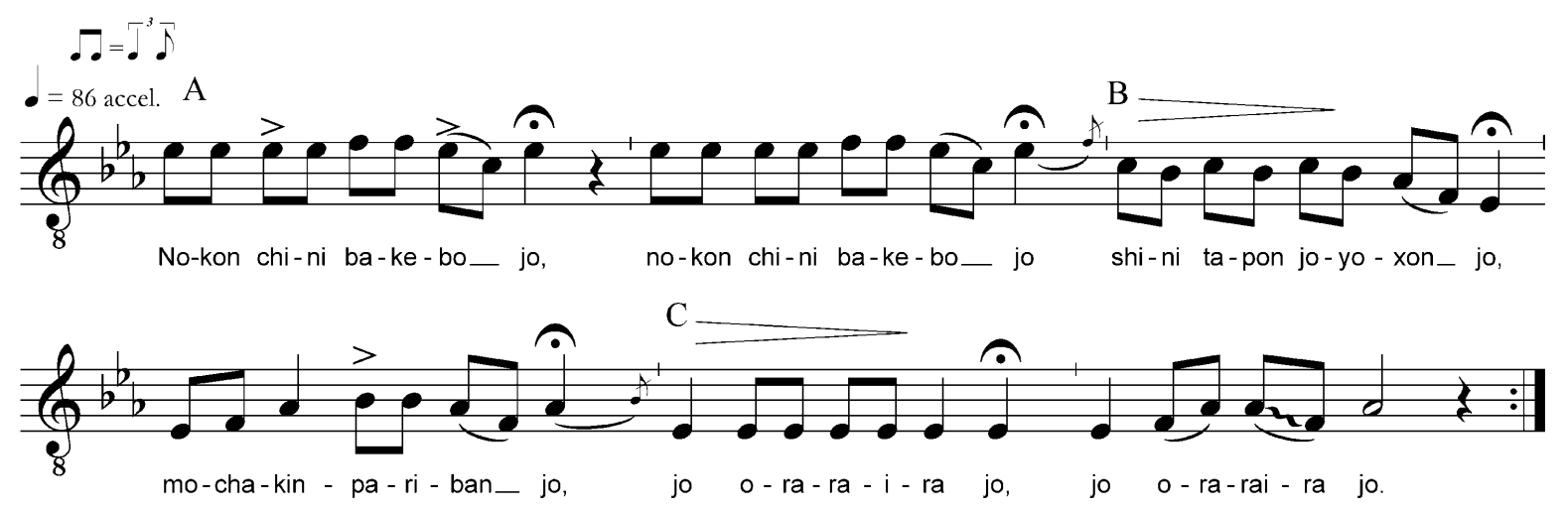

Figure 3 Transcription of the beginning of the howler monkey's song.

Well, they had their fun, laughed and commented on my performance with ojojoi, kikin yobé ('Wow, a true médico!').

This anecdote illustrates Illius' suggestion that the rendering of osanti songs is a display of the singer's own transformative faculty, of his training as a médico: the core ability of médicos is their acquired power intentionally to transform into an animal or spirit while retaining the ability to return again from this endeavour as a Real Human. This transformative faculty is also a prerequisite for singing osanti. Only a person who has the knowledge of transformation is believed by his peers to be able convincingly to perform osanti-although these songs do nothing magical and they are not thought to produce any effect besides laughter. Let us analyse the first example, a song performed by the howler monkey roo.

The song's musical structure (Figure 3) exhibits a typical form of the shiro bewá: verses are grouped in musical phrases of mostly five beats in length (separated by ticks in the transcription). The first phrase is relatively high pitched and repeated (A), followed by one descending and one ascending phrase (B) and concluded with a relatively low pitched sequence of phrases $(\mathrm{C})$, starting an octave lower than (A). But there are two minor 'singing errors': the phrases marked with $(\mathrm{C})$ are, compared with a 'correctly performed' shiro bewá, too low and monotonous, they imitate the howler's prolonged roar (also in the lyrics: jo oraraira jo are not Shipibo, nor 'human' words). Furthermore, in a human shiro bewá, the final syllable of each phrase has to be je. This is an onomatopoeic particle with high significance; it means affirmation and can also be glossed as 'melody' in music theory. Je is an essentially human syllable in Shipibo understanding. Here, the howler is almost perfect in singing like Real People, but fails in these two musical details, he roars at the end and falsely pronounces the syllable jo, hinting at his impressive call. With this, he reveals that although he may be a Real Human in his own experience, he is different from the Shipibo. In the lyrics, the howlers appear very human, too. The song is sung by the male leader of a polygamous group: ${ }^{8}$

\footnotetext{
${ }^{8}$ Excerpts, performed by Rafael Rodriguez Yui in 2004 and Pascual Mahua Ochavano in 2005. Phonogrammarchiv (Vienna) archive numbers D 5293 and D 5544.
} 
Lyrics 1: Osanti by the Howler Monkey Roo.

1. nokon chiní bakebo jo

2. shini tapon joyoxon jo

3. mochakinpariban jo

4. jo oraraira jo

5. noara nawan anake jo

6. iki itaibi jo

7. inkan yami kanakan jo

8. ratéresibawanke jo

9. xomi nishi ponyaman jo

10. nokon awinbobetan jo

11. bewashaman noikanwe jo

12. oken chixbabekoni jo
My younger children

form a row on top of a palm tree and are going to worship the sun while crying hooh (onomatopoeic word.)

The foreigners (nawa) could kill us, this may happen, because the flash from the Inca's iron [a gun] already gave us a fright before

On the branches of a big tree together with my wives we sing to each other in love while their buttocks wobble

The lyrics illustrate the monkeys' presumed humanness, their dealing with foreigners and a pun. The pun is delivered rather directly at the end (lines 9-12), where the male singer sings love songs together with his many wives and while they sing the wives' buttocks wobble. This is fun for Shipibo listeners who imagine the monkeys behaving in this way. Although wobbling buttocks are not a sole property of howlers, they are a typical feature of the female howlers' physiognomy that is highlighted and exploited in this phrase. This is one of the very few instances of obscenity in osanti lyrics. In both the examples presented later and in other details of the howler's song text, the humour is not bawdy but very subtle.

In lines $1-4$, the singer describes his children worshipping the sun (mochakin). The mochai ritual complex is no longer performed among Shipibo but in former times it was staged for collectively transcending the borders of humanness in order to worship the sun, heal the sun or the moon in times of eclipse, and also for summoning and transforming into celestial or demonic non-human persons (Brabec de Mori 2011a: 447-64). This essential ritual for negotiating the ontological status of Real People in the complex and partially overlapping multiverse is here also performed by the howlers, confirming that they are Real People in their own perspective.

Lines 5-8 demonstrate their relation to Shipibo people. The singing leader warns his fellow monkeys to take care of the foreigners (nawa), because they may shoot them with guns (the Inca's flashing iron). This feature is similarly astonishing because-theoretically-it could be sung in exactly the same terms by a Shipibo singer frightened of approaching whites (or, for example, guerrilla fighting groups during the Peruvian civil war). Historically speaking, Shipibo people know very well what life is like when in the howlers' position (except for the generic wobbly buttocks, of course).

From the analysis of both musical form and lyrics it can be deduced that this song is thought to originate from a singing howler monkey, although it is performed by a Shipibo male singer who is a specialist médico. The monkeys behave humanly in a convincing way, despite the small instances where they reveal their non-human identity. They also engage actively (here, evading) in their relationship with 'cannibal' enemies who appreciate monkey soup. 
Let us pause for a moment to analyse what is considered funny here by Shipibo listeners. First, the not-exactly-correct singing of the emically well-known shiro bewá form. This resembles humour in music in a way equally well known in western society. One may, for example, have heard recordings by Florence Foster Jenkins singing opera arias and appearing ridiculous to people who know how these arias are supposed to be sung 'correctly'. The monkeys think that they sing 'beautifully' or 'correctly' (it is said that also Foster Jenkins thought she could sing brilliantly). ${ }^{9}$ From the monkeys' perspective the concluding syllable they sing is je, they feel the same quality of 'correctness' that Shipibo people sense when hearing je. Therefore the monkeys consider their song a beautiful shiro bewá. However, the Shipibo (and fellow humans, even tape-recorders) hear the same sound as jo. From the Shipibos' perspective, the monkeys fail to sing 'correctly', so they appear ridiculous. Second, the pun with the wobbly buttocks is considered funny. But there are more humorous facets hidden in the performance context. Imagining how the howlers' song is performed subsequently after a very serious healing session, the audience may sense a release from anxiety towards laughter and lightness. Furthermore, it is considered funny that the médico sings as if he was transformed into a howler monkey. Applying the (dangerous, serious and powerful) transformative faculty on the magically powerless monkey would be an incongruent act (the Incongruity Theory of Humour, Carroll 2003: 347). Finally, and most delicately, Shipibo people laugh about perspectivism. That is, they are amused by the fact that the howlers think they are Real People. Simply imagining howlers doing mochai when 'singing' in the early morning, worshipping the sun, makes Shipibo listeners cheer up. What is understood in a very serious way connected to predation and cannibalism by most perspectivist anthropologists is ridiculed by the indigenous people themselves (a pun completely unintended but nevertheless cheerful).

The next example shows another sort of subtle humour and illustrates a slightly different form of relationship to Shipibo from the perspective of the (zoologically unidentified) aquatic bird jenenponpo. The jenenponpo similarly performs a shiro bewá in a musical form very closely related to the one performed by the howler. Here, the revealing detail is again coded in the syllables concluding the phrases: the bird cannot pronounce it correctly and utters on on ri (onomatopoeic syllables): ${ }^{10}$

\section{Lyrics 2: Osanti by the Aquatic Bird Jenenponpo.}

1. nokon tae kenéya on on ri

2. tae kenéyaninbi on on ri

3. winawinaboai on on ri

4. en chaikonintsi on on ri

5. nonti toron axona on on ri

6. oniskain ninike on on ri

\begin{abstract}
My feet show design patterns With those patterned feet I continue paddling and paddling My poor chaikoni makes his canoe sound so noisily that I have sadly to retire
\end{abstract}

\footnotetext{
${ }^{9}$ See Brittan (2010) for more details on (deliberate) musical failure and an alternative interpretation of Foster Jenkins' ineptitude.

${ }^{10}$ Performed by Francisco 'Pancho' Mahua Ahuanari, 2005 (D 5350).
} 
Much like the howler monkey, the bird seems to be a Real Human at the first glance but reveals its otherness with the on on ri syllables, as well as with hints hidden in the lyrics: First, it mentions its designed feet (tae kenéya). The kené designs (see Figure 1) are genuinely Shipibo and are used in general to confirm their humanness and social status. For festivities, Shipibo may paint their faces, hands, and feet with kené. However, the bird sings that it is paddling with these designed feet; a Shipibo would, of course, paddle with a paddle (winti) that he manoeuvres with his hands (note that also this detail is subtly constructed: winti paddles, at least in former times, were often decorated with carved kené patterns, see Tessmann 1928: 118).

For lines 4-6 it is first necessary to explain what a chaikoni is. In former times, all Shipibo lived in an intraculturally determined 'correct' way of living but many did not behave well before the Inca, so this culture hero separated them into two groups; those we commonly know and meet, and the chaikoni. The latter did not commit the sins of the former and so the Inca sent them to live in the deep woods, hidden from view for ordinary people. Only well-trained specialists may contact these chaikoni people, who maintain the 'correct' way of living, wearing perfumed clothes, singing instead of talking, commanding all sorts of rainforest magic and being the masters of all the animals, including the mighty anacondas and jaguars.

In the jenenponpo's osanti song, the bird mentions a chaikoni. From the bird's point of view, a Shipibo fisherman in his canoe is as strange and powerful as a chaikoni is from a Shipibo's point of view (note here the historical implication: once, Shipibo and chaikoni were equals; now they are different). Therefore, the 'human' bird sees the Shipibo as 'its chaikoni'. This 'chaikoni' beats his canoe with the paddle, thus scaring fish into a net he prepared beforehand (which is not made explicit in the song but is a common fishing technique among Shipibo). Because of the noise the bird has to retire. The bird itself was fishing, too, but all its potential catch is scared away by the chaikoni (who, therefore, commands these animals by sound, as the chaikoni are thought to do). The detail lies in the suffix -tsi applied to the chaikoni in line 4 . This suffix indicates compassion. The bird knows very well that it is actually the better fisherman, working quickly and precisely with its beak without scaring away the other fish. Therefore, the joke goes against the Shipibo's clumsy fishing technique, which is funny, because Shipibo generally regard themselves formidable fishermen. This osanti is about superiority, but not a linear one. Shipibo are more powerful than jenenponpo birds in the way chaikoni are superior to Shipibo; however, the bird is the superior fisherman and, remarkably, the pun is at the expense of the Shipibo.

The conflict of appearing human but not being one, or, from the animal's perspective, being human but not appearing thus, is perfectly illustrated by the tortoise's mashá: ${ }^{11}$

\footnotetext{
${ }^{11}$ Performed by Herminia Sanancino Mozombite, 2005 (D 5467).
} 
Lyrics 3: Osanti by the Tortoise Mananxawe.

1. jawe rao kaarinx

2. bero wiso sanakon

3. ibaikanai

4. chanketitanina

5. ninaren akerix
All herbs I passed by on my way- 'nssh' (onomatopoeic) I have seen with my black eye

Again and again they say that I was unable to walk upright, but I stand very well-'issh' (onomatopoeic)

Here, fun is made directly about the tortoise lacking the ability to stand and walk upright. In lines 1-2 the tortoise affirms that it eyed all the (low-growing) herbs while walking. 'They say' in line 3 refers to Shipibo who (ignorant to reality!) do not see that the tortoise is 'really' walking upright, as Real People do. Again the hints in the lyrics are accompanied by musical ones: the mashá is truncated to a monotonous line of tones with slight microtonal fluctuation (Figure 2), as if performed by somebody who has only the dimmest idea how a mashá should be sung. The tortoise also reveals itself by repeatedly interjecting the sound 'inssh', onomatopoeic for what Shipibo hear from tortoises.

\section{The Transformative Faculty: Becoming the Other}

The following, final, example text shows what sounds like an osanti but is none. The musical form is again shiro bewá, but note here the correct human pronunciation in 'je je je’: ${ }^{12}$

Lyrics 4: Love Magic Song, by the Bird of Prey Matataon.

1. eara jain joai je je je

2. nokon xoarantibi je je je

3. xoarameyontaanan je je je

4. bari jiwi ponyaman je je

5. yaka akekawanax je je je

6. taen oten taentan je je je

7. nokon bero kereshin je

8. maxen bero kereshin je je je
From there I am coming, with my vest Having dressed up with my vest on a branch on a sunsplashed tree I sat down when passing this way, putting one foot above the other My eyes are red red like the Bixa orellana fruit juice

These lyrics seem perfect for an osanti: The bird has stripes on its breast, so it appears that it put on a vest, like Real People might do. It sits down on a tree branch, putting one foot above the other-hinting at its non-humanness, which is finally made evident by the red eyes. But there is neither an error in singing or pronunciation, nor a pun.

Therefore this song is not funny. On the contrary, Shipibo listeners are scared when hearing this. The matataon is a (zoologically unidentified) bird of prey, and its appearance is an omen of love magic. The specific matataon who sings that song is not an animal in the strict sense, but a very Real Human Shipibo: it is the manifestation of a médico who put on the bird's vest in order to dispose of the bird's ability to initiate love relationships. The médico uses the bird's agency in order to actively manipulate the world. This is not a laughing song but a serious magical song. One method of transformation is the use of mask-clothing, as Viveiros de Castro

\footnotetext{
${ }^{12}$ Performed by Misael Torres Garcia, 2004 (D 5423).
} 
(1998: 482) puts it. In the matataon case, however, the médico does not put on a mask in the literal sense but indicates that a matataon which can be seen by people in reality is actually himself in a transformed state. In Shipibo understanding, anybody can transform unwillingly (many illnesses are interpreted as incidental or incomplete transformations), but only trained specialists harness the musical power of transforming and returning without harming their original human identity. There are three main techniques used to obtain such transformed states (see Brabec de Mori 2012, 2013): with or without ingesting the hallucinogenic ayawaska brew, Shipibo médicos can transform hidden from view or in absolute darkness, expressed with intransitive verbs directly derived from names (e.g., inoti, to transform into a jaguar ino). Another technique is to infiltrate the 'nature' (niwe) of non-humans by adapting their appearance, a process called naikiti. With both techniques, the médico obtains full access to these beings' competences of perception and action. Finally, the médico can use deception by appearing similar to the target beings, mimicking their appearance and behaviour but without owning their competences, a process called paranti (to betray, to trick) in Shipibo.

During a healing ritual, the boundaries of humanness become veiled and extremely opaque. While the patient becomes an Other by being drawn beyond these borders by malign forces, the médico consciously plays with his own indifferent positionality; the ritual's main phase is highly liminal and deconstructive, the médico becomes an enigmatic entity. But his aim (when healing) lies in the reconstruction of the world with its boundaries again securely embracing the patient within the Real People's domain. Therefore he ends a session by singing protective songs and 'returning', putting off voice masks and again appearing and sounding human. Magical songs for curing and sorcery do not use metaphors of animals or spirits aiming at describing certain features of human sociality, but rather they are emanations of (prior or current) full-blown experiences of what it is like to be an animal or a spirit (cf. Brabec de Mori 2012).

Overing (2000: 77) declares her opposition to Sir James Frazer's claim that magic words were 'false words' because of his claim that: 'You cannot control natural forces with words'. Overing argues that 'the magical words of Piaroa myths have a good deal of efficacy because they have first and foremost to do with human forces' (original emphasis). This is true for Piaroa myths, and for narratives with translated metaphors. However, forces that we-in a naturalistic understanding-declare as 'natural' are located within the realm of humanness (although not of Real Humans) within an animic ontology. Agency is distributed among them and interaction with them is crucial. The key for communication is song. For the Shipibo, Illius writes that 'Music is the spirit's language, and singing is the adequate mode of communicating with them' (1997: 216; my translation). When music performance kicks in, the human voice is super-formalised to an inter-specifically intelligible medium and may exert the power of its words on human forces in agents such as howler monkeys, birds of omen, anacondas or spirits. This is underlined by the behaviour of the superhuman chaikoni, who constantly sing instead of talking and therefore are able to 
command even the most powerful rainforest agents, including spirit-animals like the jenen ino ('water-dwelling jaguar'). The power that chaikoni wield towards any other beings by producing sounds and song stands paradigmatic for the paramount role of the sonic in Shipibo cosmology and cosmological boundary work.

It is therefore interesting to differentiate between those non-human instances that produce funny osanti songs when singing through the mouth of a médico and those associated with magical songs, like the chaikoni or the matataon bird. The matataon song differs from osanti more than anything else in the respect that the singer uses the bird's superior agency for changing circumstances. He does not use the howler's or tortoise's agency in osanti singing. Here are the animals that appear in osanti songs I recorded: the howler monkey (roo), the red monkey (joshin shino), the spider monkey (iso), the dog (ochiti), a vulture (xete), a baby parrot (bawa), two more birds (jenenponpo and abokoma), the land tortoise (mananxawe) and three fish (ipo, amákiri and koyaparo). Further on appear one plant (the bush anta) and one lesser demon. These entities have in common that they possess lower competence of action or perception than Shipibo people. Therefore osanti songs, by the means of performance, reconstruct the hierarchy of beings. As long as one can laugh about somebody else, the hierarchical positioning is in favour of those who laugh. Dealing with instances of higher competence, on the other hand, is the sole domain of magical songs, where also trickery (paranti) may play a role, but this is not funny and therefore beyond the limited scope of this paper.

These borders are never set in stone and have to be maintained and negotiated. The boundaries, at least in Shipibo ontology, are neither based on a hierarchy of predators and prey as commonly suggested by perspectivism, nor do they replicate a symbolic economy of affinity. The hierarchy is based upon the agents' competences of perception and action, and the scaling is very fine-tuned and flexible. Many birds own a higher competence of perception than Shipibo and therefore may foretell the future-a competence that can be useful for a médico, as can the competences of action owned by the legendary chaikoni, or the magical and physical power of anacondas and jaguars. All these instances are addressed in magical songs. Because the medicos know and perform magical songs for summoning or transforming into these beings, they can establish social relationships with them. But with that, also the borders between médicos and Shipibo laypeople are strengthened: Médicos told me that in some cases they would make fun, together with powerful entities like the chaikoni, of others including Shipibo laypeople. However, I have not yet discovered whether chaikoni sing osanti songs from the Shipibo's perspective.

If osanti contribute to boundary work by demonstrating the médicos' superiority compared with those who are thought to sing them, a question remains: where are whites and mestizo people localised in this hierarchy of competences? I recorded an osanti song by a lesser demon who expresses how its bones bend and arch and its feet feel like iron from repeated stamping. This demon is actually a white or mestizo young adult dancing in a discotheque or at a party as viewed by conservative Shipibo people: instead of dancing in a civilised way in a mashá round dance, this person 
stamps on the ground and bends bones like a ridiculous demon. Fun can also be made of such people and boundary work can be done: by performing an osanti, the singer relegates the dancer to the realm of the non-human, specifically to the realm of non-humans with lower competences than the singer.

In most instances involving whites, mestizos or other indians, however, a different musical genre is performed that is not exclusively Shipibo: mocking songs. One médico sang such mocking songs after a healing session I recorded (D 5255-65), respectively imitating an Asháninka healer, a mestizo from downriver who is thought to cheat white visitors, and a 'gringo shaman apprentice' (Brabec de Mori forthcoming). Here, the singer imitates (mawai) the Other and, notably, neither is the musical form 'shipibicised' into mashá or shiro bewá nor are the lyrics translated. Both the mocking songs' localisation after the ritual and their function in boundary work is similar to the osanti's. But in osanti, the animals' different 'musicality' is translated (although with deliberate errors), as is their 'language'. In mocking songs these stay foreign and are directly imitated, although likewise with errors and ridiculous additions. Translation is not considered necessary in mocking as anybody can understand it. Likewise, any Shipibo may musically mock whites, mestizos or other indians, this is not restricted to médicos.

\section{Conclusions}

Mary Douglas, in her analysis of ritual jokes, extrapolates the ambiguous role of jokers in society: A joker 'has a firm hold on his own position in the [social] structure', but at the same time 'he lightens for everyone the oppressiveness of social reality' and ' $[\mathrm{h}]$ is jokes expose the inadequacy of realist structurings of experience' (Douglas [1970] 1999: 159). This refers rather to professional jokers, who, for the Amazon, are most often mentioned as trickster characters (cf. Basso 1996; Hill 2009). A tricksterish attitude can be ascribed to médicos in their ritual dealings with all forms of non-humans, many of these involving trickery (paranti), but osanti songs themselves lack any such tricks. The animal or demon protagonists in osanti songs are far from being tricksters, although some of them may be tricksters in other contexts: the tortoise mananxawe, for example, archetypically wins a race against the stag chaxo or resists the mighty jaguar ino as a protagonist in trickster stories. However, as a protagonist in osanti songs, mananxawe is simply itself and does not trick anyone (see Lyrics 3).

Although tricksters in narrative have been studied among Lowland indigenous people, humour by itself is hardly mentioned or analysed. An important contribution is Overing's (2000) paper about 'The Ludic Side of Magic'. Overing highlights the repeated surfacing of obscene and hilarious hints throughout situations commonly regarded as serious, like myth-telling or ritual curing, for example. As a result, she asserts 'generative power [to] bawdy words' (2000: 77), concluding that humour in ritual and myth-telling is a tool for achieving positive conviviality and finally fertility (this idea is further developed in Lagrou 2006). 
Recalling that osanti are most often performed after very serious healing sessions and, as one médico put it, as a test of whether the patient was again brought back to 'correct' human life, Overing's proposition can be questioned. Here, life is in perfect order if a person is able to laugh. The joke and its laughter are not tools for achieving well-being (which is achieved with magical songs), they are what is to be achieved. Among the Shipibo, humour and laughing (shiroi) are ultimate goals of techniques for constructing a world in which conviviality can be achieved. Shiroi does not lead to a good community life but results from it.

Osanti songs, however, may also serve as tools apart of post-treatment diagnosis. They demonstrate that laughing works for maintaining borders. They establish a specific joking relationship between more and less powerful entities (the médicos and the osanti singing animals). While the médicos as tricksters (cf. Basso 1996, 2009; Douglas [1970] 1999) deconstruct the world in ritual, they reconstruct it afterwards, also by singing an osanti or two after the session. As tools for ordering the world, osanti pertain to Radcliffe-Brown's proposal that the comic helps to establish order. Notably, joking (shiroi) among in-laws, towards visitors and in mocking outsiders, can be done in words, or without music and translation. Anybody can imagine (and mock) the Others' position. Osanti songs, on the other hand, can only be sung by médicos, because these are the only ones who own the transformative faculty that enables them to convincingly communicate-by translating 'from the original'-how animals, plants or demons perceive their world.

Viveiros de Castro also talks about humour but he makes a premature generalisation when he asks, based on an analogy borrowed from Clastres:

What do Indians laugh about? By analogy, I wish to ask: what are Indians afraid of? The response is, in principle (and only ever in principle ...), simple: they laugh at and fear the same things, [...] such as jaguars, shamans, whites and spirits-that is, beings defined by their radical alterity. (Viveiros de Castro 2012: 29)

Osanti songs show that this is an overt simplification. Shipibo people laugh, in principle (and only ever in principle), about Others that are clearly distinguished from those they fear. They would not laugh about, and definitely never 'at', the jaguar, shamans or spirits lest they would reveal suicidal tendencies (but they do laugh about whites, including perspectivists, who they usually do not fear). Osanti songs, furthermore, show a very interesting attitude towards animals: in humour, European perspectives can be surprisingly coherent with Amerindian ideas. Critchley (2002), with considerable scrutiny, explores whether animals can laugh, basing his argument on European history, literature and ethological studies, and concludes that only humans can laugh or sense humour. Consequently, ' $\mathrm{i}] \mathrm{f}$ humour is human, then it also [...] explores what it means to be human by moving back and forth across the frontier that separates humanity from animality, thereby making it unstable' (2002). Critchley goes on that '[w] might even define the human as a dynamic process produced by a series of identifications and misidentifications with animality' (2002: 29; original emphasis) in humour and beyond. That said, in European or naturalistic terms, humour contributes 
to boundary work marking a difference between humans and animals. For Critchley, and for the naturalistic world, animals are funny in jokes when they become (or behave like) humans, but humans appear disgusting when becoming (or behaving like) animals. Among Lowland South American societies, the picture does not appear very different. Osanti singing animals, as indicated by perspectivism, are persons, they believe that they are 'Real People' and therefore behave like humans, which finally results in them being funny when trying (and failing) to sing like humans. But with that, the osanti case also questions some of the animic or perspectivistic claims that the frontiers between animal persons and human persons are very differently treated in the Amazon when compared with naturalism. If one bears in mind that in naturalism, all animals are considered inferior to humans, the laughter about them behaving like humans seems very similar to the Shipibo's laughter about osanti-singing animals.

\section{Acknowledgements}

I express my deep gratitude to my wife Laida Mori Silvano de Brabec, to Bruno Illius, Jean Langdon, Beverley Diamond, Laure Carbonnel, Anthony Seeger and all authors in this special issue, who significantly helped me sculpting this paper out of a mess of crazy ideas.

\section{References}

Basso, Ellen B. 1996. 'The Trickster's Scattered Self'. In Disorderly Discourse. Narrative, Conflict, and Inequality, edited by Charles Briggs, 53-71. Oxford: University Press.

- 2009. 'Ordeals of Language'. In Culture, Rhetoric, and the Vicissitudes of Life, edited by Michael Carrithers, 121-37. New York: Berghahn.

Beaudet, Jean-Michel. 1996. 'Rire. Un exemple d'Amazonie' [To Laugh. An Example from Amazonia]. L'Homme 36(140): 81-99.

Brabec de Mori, Bernd. 2011a. 'Die Lieder der Richtigen Menschen. Musikalische Kulturanthropologie der indigenen Bevölkerung im Ucayali-Tal, Westamazonien' [Songs of the Real People. A Musical Anthropology of Indigenous People in the Ucayali Valley, Western Amazon]. 2 Vols. Ph.D. diss., University of Vienna, Vienna.

. 2011b. 'The Magic of Song, the Invention of Tradition and the Structuring of Time among the Shipibo (Peruvian Amazon)'. Jahrbuch des Phonogrammarchivs der Österreichischen Akademie der Wissenschaften 2: 169-92.

. 2011c. 'Tracing Hallucinations. Contributing to a Critical Ethnohistory of Ayahuasca Usage in the Peruvian Amazon'. In The Internationalization of Ayahuasca, edited by Beatriz Labate and Henrik Jungaberle, 23-47. Zürich: LIT.

. 2012. 'About Magical Singing, Sonic Perspectives, Ambient Multinatures, and the Conscious Experience'. Indiana 29: 73-101.

- 2013. 'A Medium of Magical Power: How to do Things With Voices in the Western Amazon'. In Electrified Voices. Media-Technical, Socio-Historical and Cultural Aspects of Voice Transfer, edited by Dmitri Zakharine and Nils Meise, 379-401. Göttingen: V\&R unipress.

. Forthcoming. 'From the Native's Point of View: How Shipibo-Konibo Experience and Interpret Ayahuasca Drinking with "Gringos". In Ayahuasca Shamanism in the Amazon and Beyond, edited by Beatriz Labate and Clancy Cavnar. Oxford: University Press. 
Brabec de Mori, Bernd and Laida Mori Silvano de Brabec. 2009. 'La corona de la inspiración. Los diseños geométricos de los Shipibo-Konibo y sus relaciones con cosmovisión y música' [The Crown of Inspiration. Shipibo-Konibo Geometric Patterns and Their Relations to Worldview and Music]. Indiana 26: 105-34.

Brittan, Francesca. 2010. 'Cultures of Musical Failure'. In On Bathos: Literature, Art, Music, edited by Sara Crangle and Peter Nicholls, 112-31. London: Continuum.

Carroll, Noël. 2003. 'Humour'. In The Oxford Handbook of Aesthetics, edited by Jerrold Levinson, 344-66. Oxford: University Press.

Critchley, Simon. 2002. On Humour. New York: Routledge.

Descola, Philippe. 2005. Par-delà nature et culture [Beyond Nature and Culture]. Paris: Editions Gallimard.

Douglas, Mary. 1999 [1970]. 'Jokes'. In Implicit Meanings: Selected Essays in Anthropology, edited by Mary Douglas, Second Edition, 146-64. London: Routledge.

Driessen, Henk. 1997. 'Humour, Laughter and the Field: Reflections from Anthropology'. In A Cultural History of Humour, edited by Jan Bremmer and Herman Roodenburg, 222-41. Cambridge: Polity Press.

Gieryn, Thomas F. 1995. 'Boundaries of Science'. In Handbook of Science and Technology Studies, edited by Sheila Jasanoff, Gerald E. Markle, James C. Peterson and Trevor Pinch, 393-443. Thousand Oaks: Sage Publications.

Gow, Peter. 2000. 'Helpless- the Affective Preconditions of Piro Social Life'. In The Anthropology of Love and Anger: The Aesthetics of Conviviality in Native Amazonia, edited by Joanna Overing and Alan Passes, 46-63. London: Routledge.

Halbmayer, Ernst. 2012a. 'Amerindian Mereology: Animism, Analogy, and the Multiverse'. Indiana 29: $103-25$.

- ed. 2012b. 'Debating Animism, Perspectivism and the Construction of Ontologies'. Edited dossier in Indiana 29: 8-169.

Hill, Jonathan D. 2009. Made-from-Bone. Trickster Myths, Music, and History from the Amazon. Urbana and Chicago: University of Illinois Press.

Illius, Bruno. 1997. 'Ein Lied zur Haarschneidezeremonie der Shipibo-Conibo' [A Song of the Shipibo-Conibo Haircutting Ceremony]. In Religionsethnologische Beiträge zur Amerikanistik, edited by Eveline Dürr and Stefan Seitz, 211-31. Münster: LIT.

—. 1999. Das Shipibo. Texte, Kontexte, Kommentare. Ein Beitrag zur diskursorientierten Untersuchung einer Montaña-Kultur [Shipibo. Texts, Contexts, Commentary. A Contribution to Discourse-Guided Analysis of a Montaña Culture]. Berlin: Dietrich Reimer.

—. 2003. 'Feldforschung' [Field Research]. In Ethnologie. Einführung und Überblick, edited by Hans Fischer and Bettina Beer, 73-98. Berlin: Dietrich Reimer.

Labate, Beatriz C. and Wladimyr Sena Araújo, eds. 2004. O uso ritual da ayahuasca [The Ritual Use of Ayahuasca]. Second Edition. Campinas: Mercado de Letras.

Lagrou, Els. 2006. 'Laughing at Power and the Power of Laughing in Cashinahua Narrative and Performance'. Tipití 4(1-2): 33-56.

Overing, Joanna. 2000. 'The Efficacy of Laughter: The Ludic Side of Magic within Amazonian Sociality'. In The Anthropology of Love and Anger. The Aesthetics of Conviviality in Native Amazonia, edited by Joanna Overing and Alan Passes, 64-81. London: Routledge.

Pachucki, Mark A, Sabrina Pendergrass and Michèle Lamont. 2007. 'Boundary Processes: Recent Theoretical Developments and New Contributions'. Poetics 35: 331-51.

Paulitz, Tanja. 2012. Mann und Maschine [Man and Machine]. Bielefeld: Transcript.

Radcliffe-Brown, A. R.1940. 'On Joking Relationships'. Africa: Journal of the International African Institute 13(3): 195-210. 
Tessmann, Günter. 1928. Menschen ohne Gott. Ein Besuch bei den Indianern des Ucayali [Men Without God. A Visit to the Ucayali Indians]. Stuttgart: Strecker und Schröder.

Townsley, Graham. 1993. 'Song Paths. The Ways and Means of Yaminahua Shamanic Knowledge'. L'Homme 33(2-4): 449-68. doi:10.3406/hom.1993.369649

Viveiros de Castro, Eduardo B. 1998. 'Cosmological Deixis and Amerindian Perspectivism'. Journal of the Royal Anthropological Institute N.S. 4(3): 469-88. doi:10.2307/3034157

. 2012. 'Immanence and Fear. Stranger-events and Subjects in Amazonia'. HAU: Journal of Ethnographic Theory 2(1): 27-43. 